\title{
Autologous Transfusion - from Euphoria to Reason: Clinical Practice Based on Scientific Knowledge
}

Supreme Court ruling demands the application of autologous blood transfusion [1]. Moreover, governmental health care officials also wish for its regular use [2]. In times of increasing limitation or even shortage in available resources, it is essential to critically analyze, discuss, and outweigh benefits and risks of autologous versus allogeneic blood transfusion from different points of view:

- Although immunomodulation 'triggered' by allogeneic blood transfusion is demonstrated, its clinical impact is still unresolved.

- So far, cost-effectiveness analyses considered only the potential risks of transmission of viral diseases by allogeneic blood. The potential risk connected with an increase in postoperative bacterial infection rate in surgical patients transfused with allogeneic red blood cells make recalculations of cost-effectiveness analyses of autologous/allogeneic blood mandatory and reasonable on health economic reasons.

- Though mechanical processing of perioperatively salvaged wound blood is routinely administered, its basic physical principles are not well known among users.

- The clinical relevance of leukocyte activation by blood salvage and mechanical processing is not resolved and understood yet.

- In oncologic surgery, the safety of perioperatively salvaged, mechanically processed and irradiated red blood cells are still discussed controversially.

- There are further controversial discussion and unanswered questions on application of perioperative blood salvage and mechanical processing in special types of surgery or co-existing diseases.

- Quality management concerning patients' care gains growing importance in clinical medicine. However, at least in blood salvage with mechanical processing, clear-cut parameters with respect to the quality of the final blood prod- uct to be transfused are still open for discussion and consensus.

- What are the rational medical reasons for a different or an identical 'transfusion trigger' in allogeneic versus autologous blood transfusion?

- 'New' indications for 'old' drugs are supposed to decrease perioperative blood loss and transfusion requirements.

- Hemoglobin-based oxygen carriers are (still/again) critically evaluated and are still (far ?) away from routine clinical administration.

During this second international/interdisciplinary symposium held in Nottwil, Switzerland on January 18-19, 2002, international experts and audience thoroughly discussed the abovementioned topics with respect to actual scientific data and current state of clinical practice. The purpose of this meeting was not only to answer open questions but also to provoke new questions on 'old topics'. It was also intended to critically question 'so-called' established routine clinical practice and, thus, to continue in giving autologous transfusion measures a sound and scientifically based background and thereby to proceed with establishing evidence based medicine in autologous transfusion, too.

A scientifically based way of patients' care is not only beneficial to the individual patient, and thus medically reasonable, but it is also economically rational while still ethical. 'For many physicians it is hard to comprehend that medical and economical ethics belong together. Only what we save today, can we spend for investments tomorrow, that will cause benefit in the future' (translated from German into English according to [3]). According to von der Schulenburg [4], 'economical acts and thoughts are ethical acts when resulting in careful spending and less wastage of the limited resources. It is only during times of shortages that true ethics become obvious' (translated from German into English according to [4]). By the agreement of the editors it is possible to publish the

\begin{tabular}{ll}
\hline KARGER & @ 2002 S. Karger GmbH, Freiburg \\
$\begin{array}{l}\text { Fax +497614520714 } \\
\begin{array}{l}\text { E-mail Information@Karger.de } \\
\text { www.karger.com }\end{array}\end{array}$ & $\begin{array}{l}\text { Accessible online at: } \\
\text { www.karger.com/journals/iut }\end{array}$
\end{tabular}


lectures presented on this international/interdisciplinary symposium in German in Anästhesiologie, Intensivmedizin, Notfallmedizin, Schmerztherapie (Thieme, Stuttgart), and in English in Infusion Therapy AND Transfusion Medicine (Karger, Freiburg). The topic of autologous transfusion covers the interest both of anesthesiologists and transfusion specialists. Therefore, this kind of publication in two different languages and journals was chosen by the guest-editors in order to enable the presentation of the papers to the broad audience of two different medical specialties. As the articles appear in two different languages, they are not considered a 'double publication' on the corresponding topic. The organizers/guest-editors are very grateful both to the editors of these scientific journals for the opportunity to present the papers of this symposium and to the authors for their appreciated contributions.

G. Singbartl (Hamburg), W. Schleinzer (Nottwil)

\section{References}

1 Bundesgerichtshof: BGH-Urteil vom 17.12.1991. AZ: VI ZR 40/91.

2 Von Auer F: Autologous Transfusion - Pros and Cons from the Health Policy Perspective. Infus Ther Transfus Med 2002; 29:110-116.

3 Von Eiff W. Sparen im Krankenhaus. Westfälische Nachrichten, Münster, 21.01.2000.

4 Von der Schulenburg J-M: Vorwort; in: von der Schulenburg J-M (Hrsg): Ökonomie in der Medizin. Schattauer, Stuttgart, 1996, pp V-VIII. 